\section{NATIONAL FLOUR AND BREAD}

\section{From the Scientific Adviser's Division, Ministry of Food}

$\mathrm{T}$ HIS report, the fifth to be issued ${ }^{1}$, covers the samples of flour examined in the period January 1 to September 2, 1944, and loaves from January 1 to October 2.

\section{Quality of Flour}

423 samples were analysed with the following results :

\begin{tabular}{|c|c|c|c|}
\hline \multicolumn{2}{|c|}{ Fibre } & \multicolumn{2}{|c|}{ Vitamin $\mathrm{B}_{1}$} \\
\hline Value per cent & $\begin{array}{l}\text { Per cent } \\
\text { of samples }\end{array}$ & I.U./gram & $\begin{array}{l}\text { Per cent } \\
\text { of samples }\end{array}$ \\
\hline $\begin{array}{ll}0.4 & \text { or less } \\
0.5 & , \\
0.55 \quad, \\
0.6 & , \\
0.7 & , \\
0.8 \quad, \\
\end{array}$ & $\begin{array}{l}10 \cdot 9 \\
52 \cdot 7 \\
70 \cdot 7 \\
80 \cdot 7 \\
92 \cdot 7 \\
98 \cdot 1\end{array}$ & $\begin{array}{l}1.1 \text { or more } \\
1.05 \quad,, \\
1.0 \quad,, \\
0.95 \quad,, \\
0.9 \quad, \\
0.8 \quad,\end{array}$ & $\begin{array}{r}3 \cdot 3 \\
12 \cdot 3 \\
35 \cdot 7 \\
62 \cdot 1 \\
82 \cdot 0 \\
97 \cdot 1\end{array}$ \\
\hline
\end{tabular}

The fibre figures are corrected for any added white flour.

Riboflavin, Nicotinic Acid, Iron, Protein, Ash and Maltose. For these determinations the samples received in each of the months January-June inclusive were compounded.
It will be observed that the first two groups totalled 55 per cent against 80 per cent for the flours baked under ideal conditions in the laboratory.

This work was carried out at the Cereals Research Station, Ministry of Food, St. Albans.

${ }^{1}$ See Nature, 149, 460 (1942) ; 150, 538 (1942) ; 151, 629 (1943); 153, 154 (1944).

\section{PHYSICO-CHEMICAL ANALYSIS IN U.S.S.R.}

TN 1904 Prof. N. S. Kurnakov (1860-1941) invented I a new form of recording pyrometer which was a great improvement on that of Roberts-Austen. In 1910 Prof. A. A. Baikov still further improved this pyrometer by a modification which allowed the recording of the differential curve to be superimposed on the ordinary cooling or heating curve. This apparatus provided a very delicate method for the thermal analysis of alloys and minerals, called by Kurnakov in 1913 'physico-chemical analysis'. Through the initiative and enthusiasm of Kurnakov, a very flourishing school of research was established, and in 1918 a special Institute of Physico-Chemical Analysis was founded at the Academy of Sciences.

\begin{tabular}{|c|c|c|c|c|c|c|c|c|}
\hline Month & $\begin{array}{l}\text { No. of } \\
\text { samples }\end{array}$ & $\begin{array}{l}\text { Riboflavin } \\
(\mu \mathrm{gm} . / \mathrm{gm} .)\end{array}$ & $\begin{array}{c}\text { Nicotinic acid } \\
(\mu \mathrm{gm} . / \mathrm{gm} .)\end{array}$ & $\begin{array}{c}\text { Iron } \\
\text { (mgm./100 gm.) }\end{array}$ & $\begin{array}{l}\text { Protein } \\
\text { per cent }\end{array}$ & $\begin{array}{c}\text { Ash }^{*} \\
(\text { per cent) }\end{array}$ & $\begin{array}{c}\text { Fibre } \\
\text { (per cent) }\end{array}$ & $\begin{array}{c}\text { Maltose } \\
\text { (per cent) }\end{array}$ \\
\hline $\begin{array}{l}\text { January } \\
\text { February } \\
\text { March } \\
\text { April } \\
\text { May } \\
\text { June }\end{array}$ & $\begin{array}{l}72 \\
64 \\
60 \\
60 \\
40 \\
50\end{array}$ & $\begin{array}{l}1 \cdot 2 \\
1 \cdot 2 \\
1 \cdot 3 \\
1 \cdot 4 \\
1 \cdot 4 \\
1 \cdot 3\end{array}$ & $\begin{array}{l}17 \\
17 \\
17 \\
17 \\
16 \\
17\end{array}$ & $\begin{array}{l}2 \cdot 15 \\
2 \cdot 12 \\
1 \cdot 94 \\
1 \cdot 98 \\
2 \cdot 01 \\
2 \cdot 20\end{array}$ & $\begin{array}{l}10.9 \\
10.8 \\
10.0 \\
10.8 \\
10.9 \\
10.8\end{array}$ & $\begin{array}{l}1 \cdot 0 \\
0 \cdot 97 \\
0 \cdot 96 \\
0 \cdot 94 \\
0 \cdot 96 \\
1 \cdot 04\end{array}$ & $\begin{array}{l}0.50 \\
0.50 \\
0.50 \\
0.50 \\
0.50 \\
0.50\end{array}$ & $\begin{array}{l}2 \cdot 35 \\
2 \cdot 3 \\
2 \cdot 3 \\
2 \cdot 1 \\
2 \cdot 05 \\
2 \cdot 3\end{array}$ \\
\hline
\end{tabular}

* All the flours were fortified with calcium carbonate at the rate of $7 \mathrm{oz}$. per sack of $280 \mathrm{lb}$. The ash due to this addition would average 0.12 per cent. No skim milk powder was added after March 1944 .

Average figures for National flour in the period were therefore:

\begin{tabular}{|c|c|c|c|}
\hline$B_{1}$ & 0.95-1.0 I.U./gm. & Protein & $10 \cdot 7$ per cent \\
\hline $\begin{array}{l}\text { Riboflavin } \\
\text { Nicotinic acid }\end{array}$ & $1 \cdot 3 \mu \mathrm{gm} . / \mathrm{gm}$ & Fibre & 0.50 \\
\hline $\begin{array}{l}\text { Nicotinic acid } \\
\text { Iron }\end{array}$ & $17.07 \mathrm{mgm}$ & Ash & 0.98 \\
\hline 11 & $2.07 \mathrm{mgm} . / 100 \mathrm{gm}$. & Maltose & $2 \cdot 2$ \\
\hline
\end{tabular}

Granularity. In 1944 (up to October 4) 549 samples of flour have been examined with the follow. ing results :

\begin{tabular}{ccc} 
Samples & $\%$ over 5 silk & $\%$ over 8 silk \\
$1-100$ & $1 \cdot 2$ & $4 \cdot 7$ \\
$101-200$ & $1 \cdot 1$ & $4 \cdot 4$ \\
$201-300$ & $0 \cdot 8$ & $4 \cdot 1$ \\
$301-400$ & $0 \cdot 7$ & $3 \cdot 7$ \\
$401-549$ & $1 \cdot 0$ & $4 \cdot 3$ \\
\multicolumn{2}{c}{ Aperture No. 5 silk $=0 \cdot 270 \mathrm{~mm}}$. \\
, No. $8,,=0 \cdot 190,$,
\end{tabular}

Baking Quality. All the flours were test-baked under optimum conditions of water absorption and fermentation, and the resulting bread graded according to quality (commercial standards).

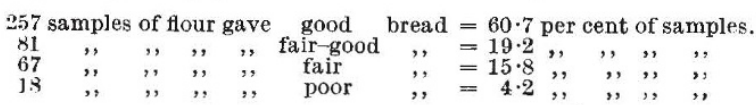

\section{Quality of Bread}

3,358 loaves from different parts of Great Britain were graded for quality (commercial standards).

$$
\begin{aligned}
& \text { Good }=461 \text { loaves }=13 \cdot 7 \text { per cent } \\
& \text { Fair-Good }=1393,, \quad=41.5,,,
\end{aligned}
$$

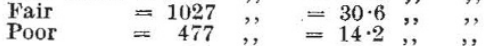

The scope and purpose of this Institute was defined by Kurnakov in the following words: "The Institute of Physico-Chemical Analysis has for its aim the study of the relations between the composition and the measurable properties of systems in equilibrium of two or more components. Being in reality one of the subdivisions of general chemistry, physicochemical analysis can be of a wide application in the border regions of theoretical and applied science - mineralogy, petrology, geology, metallurgy and applied and structural mechanics. It is a very significant fact that a systematic investigation of the diagram 'composition-properties', the essential method of this new chemical discipline, allows us to draw conclusions about the nature of solid, liquid or gaseous substances, without subjecting them to the usual chemical operations of separation. Because of that, a whole range of substances-alloys, glasses, slags, rocks, liquid and solid solutions, colloidal systems and various ores-are now included within the range of a systematic chemical investigation" ".

In 1940 the friends of N. S. Kurnakov decided to celebrate his eightieth anniversary by publishing a special volume of collected papers. The sad event of Kurnakov's death on March 19, 19413, made it necessary to recast the proposed volume and a memorial volume was published instead ${ }^{4}$ This volume contains twenty-nine articles written by Kurnakov's close associates and friends. The first eight articles deal with the biography, bibliography and the scientific work of Kurnakov. Every application of the physico-chemical analysis-alloys, organic 
and complex compounds, minerals and ores-is discussed in a special article by a leading authority on this subject. The remaining articles deal with original research and they include the following topics : thermographic methods, viscosity of liquid systems, properties of various chemical systems and alloys, potash salts, etc. The volume is well printed and provided with the portrait of N. S. Kurnakov and numerous plates of photomicrographs and diagrams. Unfortunately there are no English summaries.

It is rather difficult to give an adequate account of the achievements of Kurnakov's sehool of research, but specialists in given branches of chemistry and other sciences are probably acquainted with the abstracts of Russian papers and with the papers published in the Z. anorg. Chem. and J. Inst. Metals. The whole range of these publications can be roughly assigned to three sections: (1) metals, (2) minerals and ores, and (3) general chemistry. The works dealing with metals are chiefly concerned with the thermal study of alloys from the point of view of the phase rule, and a very detailed correlation of the composition with viscosity, hardness, electro-conductivity, etc., is usually made. The works dealing with minerals and ores cover a wider ground. First in order of importance comes the study of the equilibrium of salt solutions, a study which not only made a valuable contribution to theoretical science but also greatly helped in the development of Russian salt deposits and the salt industry. The application of physico-chemical analysis to other minerals and ores has embraced practically all classes of minerals : silicates, carbonates, oxides, borates, native e!ements, etc. Probably the most outstanding achievement was the study of the minerals of the platinum group, clay minerals and bauxitic minerals, a work which had a most important practical application in the U.S.S.R. Of the problems concerned with the general chemistry one may mention the study of organic compounds, compounds with complex radicals, the general study of equilibrium systems and the topology of the equilibrium diagram.

\section{S. I. TOMKEIEFF.}

' Kurnakov, N. S., "An Introduction to Physico-chemical Analysis", Publication of the Acad. Sci. U.S.S.R., 1st ed., pp. 87 (1925) 4 th ed., pp. 562 (1940) (in Russian). 2 Kurnakov, N. S., Ann. Inst. Phys.-Chem. Anal., 2, 473 (1924)
(in Russian).

${ }^{3}$ Briscoe, H. V. A., Nature, 148, 310 (1941).

- Annales du Secteur d'Analyse Physico-Chimique. Inst. de Chimie Générale, Acad. Sci. URSS., 14 (1941) (in Russian).

\section{SOLAR RADIATION OBSERVA- TIONS AND VOLCANIC DUST}

T was observed by Dr. C. G. Abbot that dust from 1 the Alaskan volcano Katmai in June 1912 affected the transparency of the atmosphere in the northern hemisphere, but failed to influence the pyrheliometric observations at Arequipa, Peru. This led George G. Gallagher of Glendale, California, to inquire whether or not dust from southern hemisphere volcanoes influenced the atmosphere in the northern hemisphere. This matter has just been investigated by L. B. Aldrich from the records of the Smithsonian solarradiation stations for the Chilean Andes eruptions of April 1932*.

* "Smithsonian Pyrheliometry and the Andean Volcanic Fruptions of April 1932", by L. B. Aldrich. Smithsonian Misc. Coll., 104, No. 6, July 3,1944 .
The Andean eruptions of 1932 started on April 10 , involving some seven volcanoes extending two hundred miles along the Chile-Argentine border from Tupungato (altitude 2 ',000 ft., lat. $33 \cdot 5^{\circ} \mathrm{S}$.) southward to Quizapu (altitude about 10,000 ft.). Loud explosions were heard 100 miles on either side of the volcanoes. The explosions continued for three days. Surrounding towns were in semi-darkness owing to the steady fall of dust and ashes. In Montevideo, 850 miles away, the steady fall of dust continued for many hours. The late Dr. C. Davison estimated the fall of dust over the area to be more than five cubic miles. Capt. R. Wooten, United States Air Attaché at Santiago, who flew across Quizapu at an altitude of 14,000 ft., estimated that at the time of greatest activity the smoke column rose to a height of $30,000 \mathrm{ft}$. Evidences of unusual dust in the atmosphere were noted at Wellington, New Zealand, on May 7, reaching a maximum about May 26. Unusual skies were also reported during May from various places in South Africa.

During this time the Smithsonian Institution was operating solar-radiation stations at Montezuma (latitude $22^{\circ} 40^{\prime} \mathrm{S}$., longitude $68^{\circ} 56^{\prime} \mathrm{W}$.) and at Table Mountain, California (latitude $34^{\circ} 22^{\prime} \mathrm{N}$., longitude $117^{\circ} 41^{\prime}$ W.). At both these stations, on all days when the sky around the sun was clear, observations were made with the silver-disk pyrheliometer, measuring the total solar radiation received upon a surface normal to the radiation. Simultaneously, readings were taken with a pyranometer, measuring the brightness of the sky in a circular zone about $10^{\circ}$ wide, concentric with the sun. These pyranometer readings are an index of the quantity of dust. in the atmosphere. Values of pyrheliometry and pyranometry at air mass $2 \cdot 0$ (solar altitude $30^{\circ}$ ) were selected from the observations and used uncorrected to mean solar distance. These were grouped by months and so chosen that the average amount of water vapour in the air above the station was the same in each year for a given month. The amount of water vapour in the air may be represented by the spectrobolometrically determined precipitable water value. The year 1930 was taken as a standard for comparison. The following tables, obtained by L. B. Aldrich, indicate the results of the investigation.

PERCENTAGe DEVIATIONS OF PYRHELIOMETRY AND SOLAR OONSTANTS FROM OORRESPONDING MONTH OF 1930. Pyrheliometry

\begin{tabular}{|c|c|c|c|}
\hline \multirow{3}{*}{$\begin{array}{c}\text { Month } \\
\text { May } 1932\end{array}$} & \multicolumn{2}{|c|}{ Pyrheliometry } & \multirow{3}{*}{$\begin{array}{c}\text { Solar Constant } \\
\text { per cent } \\
-0.4\end{array}$} \\
\hline & Montezuma & Table Mountain & \\
\hline & $\begin{array}{c}\text { per cent } \\
-3.7\end{array}$ & $\begin{array}{c}\text { per cent } \\
+0.8\end{array}$ & \\
\hline June ,, & $-3 \cdot 4$ & -0.5 & $-0 \cdot 1$ \\
\hline July ", & $-2 \cdot 6$ & -0.1 & -0.1 \\
\hline Nov. 1933 & $\begin{array}{l}-2.1 \\
-0.1\end{array}$ & $\begin{array}{r}0.0 \\
-0.4\end{array}$ & 二 0.2 \\
\hline
\end{tabular}

PERCENTAGE CHANGE OF SKY BRIGHTNESS AROUND THE SUN FROM PERCENTAGE CHANGE OF SKY BRIGHTNESS AROUND THE

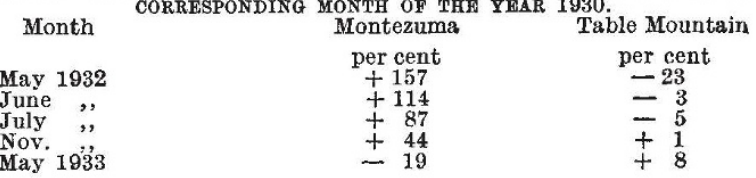

No effect of the Andean eruptions is discovered in the Table Mountain, California observations. A definite effect occurs in the Montezuma pyrheliometer values, with a maximum of 3.7 per cent depletion in May 1932, and an average of $3 \cdot 0$ per cent for the months May, June, July, November. This agrees with Mr. Gallagher's estimate. 